\title{
Variations in the Properties of Potato Virus $X$ and their Effects on its Interactions with Ribonuclease and Proteolytic Enzymes
}

\author{
BY F. C. BAWDEN AND A. KLECZKOWSKI \\ The Rothamsted Experimental Station, Harpenden, Herts
}

SUMMARY: When concentrated by precipitation with acid and salts, or by highspeed centrifugation, potato virus $X$ tends to become insoluble though still remaining infective and serologically active. This greatly complicates purification and no method was found that could be relied upon to give good yields of virus with constant properties. Insolubility is correlated with the aggregation of virus particles to form long threads that become entangled, but it is probable that combination of the particles with some cell constituents is also concerned.

Insoluble preparations dissolve slowly when incubated with $\mathrm{pH} 7.5$ borate buffer, and rapidly in the presence of trypsin or chymotrypsin. Both of these enzymes hydrolyse virus $X$, chymotrypsin being the more effective, but different strains of the virus vary in their susceptibility.

Ribonuclease readily hydrolyses the nucleic acid derived from virus $X$, but seems to have no enzymic action on the active virus. When mixed with the virus, the enzyme combines with it and reversibly inhibits infectivity. At $\mathrm{pH} 7$ the addition of ribonuclease to soluble virus preparations causes loss of anisotropy of flow, a fall in precipitin titre, and the production of an insoluble complex. Incubation at $\mathbf{p H ~ 7 . 5}$ with borate buffer slowly dissolves the complex and restores the original properties of the virus; the rate of re-solution is increased by the presence of trypsin. Some preparations of the virus were partially decomposed by incubation with borate buffer, and sometimes the rate of decomposition was increased in the presence of ribonuclease.

Of the plant viruses that have been isolated in the form of nucleoproteins, potato virus $X$ is exceptional in being susceptible to the proteolytic enzymes trypsin, pepsin and papain (Bawden \& Pirie, 1936, 1938). Tobacco mosaic virus, which resembles virus $X$ in forming rod-like particles of variable lengths and contains the same proportion of nucleic acid to protein, is hydrolysed by these enzymes only if it is first denatured, though trypsin combines with it and inhibits its infectivity (Bawden \& Pirie, 1937; Kleczkowski, 1944). Similarly, ribonuclease combines with tobacco mosaic virus, and is an even more powerful inhibitor of infectivity than trypsin, but it does not hydrolyse the nucleic acid unless the virus is first denatured (Loring, 1942). It seemed of some interest, therefore, to determine the effects of ribonuclease on virus $X$; the work described below was started for this purpose, but for various reasons the problem proved unexpectedly complex. There was little difficulty in demonstrating that any enzymic activity ribonuclease may have on virus $X$ is small compared with that of the proteolytic enzymes, but it was less easy to find with certainty whether or not it has any such activity. The enzyme inhibits infectivity and its interactions with the virus also affect serological reactions, so that quantitative interpretations of infectivity and precipitin tests are uncertain. By far the greatest complication was the irregular behaviour of the 
virus during the course of purification, and its tendency to become insoluble, a phenomenon not encountered with tobacco mosaic or other viruses that have been purified. No method of purification was found that could be relied on to give preparations with reproducible properties, and although consistent results were obtained in repeated tests on the same preparation, these might not be reproduced on other preparations. The work was therefore extended to study some of these variations in the behaviour of virus $X$ during purification and their effect in determining the interactions between the virus and enzymes.

\section{MATERIALS AND METHODS}

Three strains of potato virus $X$ were used, namely, $X^{K}, X^{S}$ and $X^{Y}$. Most of the work was done with tomato (Lycopersicum esculentum, var. Kondine Red) and tobacco (Nicotiana tabacum, var. White Burley) as host plants, but some tests were also made with $X^{K}$ and $X^{Y}$ propagated in $N$. glutinosa, Datura stramonium and potato (Solanum tuberosum, vars. Majestic and Doon Star). In tomato and potato plants $X^{K}$ and $X^{S}$ cause a severe mosaic with much necrotic spotting and deformity of the leaves; in tobacco, Nicotiana glutinosa and Datura stramonium, they cause necrotic local lesions and systemic symptoms of the ringspot type. In all the hosts, $X^{P}$ causes a bright yellow interveinal mosaic with little or no necrosis. However, the precise symptoms caused by any of the strains vary considerably with the season and with the age and condition of the host plants at the time of inoculation. For producing large quantities of virus $X$, tomato is the most suitable host, as young plants produce much sap which has a virus content twice as great as that from tobacco or potato. On the other hand, tobacco has the advantage that purification of the virus usually proceeds more smoothly. In the various hosts used, strains $X^{K}$ and $X^{\boldsymbol{Y}}$ occur at approximately twice the concentration of $X^{S}$. The virus content of sap is higher from plants raised during the winter than during the summer, and purification is also easier with sap from the former. Sap from tomato plants, infected with $X^{K}$ and $X^{Y}$, has sometimes during the winter reached a virus content of $2 \mathrm{~g}$./l. Leaves are picked from plants about a month after infection, when they are showing good symptoms. After removing the petioles and the largest parts of the main veins, the laminae are minced by passage through a domestic meat mincer, and the sap which is expressed by squeezing the minced leaves in a cloth bag forms the starting material for purification.

Infectivity tests were made using strains $X^{K}$ and $X^{S}$ by the local lesion method with tobacco or Nicotiana glutinosa as a test plant. Precipitin tests were made by methods previously described (Bawden \& Pirie, 1936), $1 \mathrm{ml}$. of antiserum at a constant dilution being added to a series of tubes containing $1 \mathrm{ml}$. of virus preparation at different dilutions. The greatest dilution to give a precipitate visible to the eye after $3 \mathrm{hr}$. incubation in a water-bath at $50^{\circ}$ was taken as the precipitin titre. Anisotropy of flow was observed merely by examining the fluids in polarized light as they are tipped from end to end of half-filled tubes $0.5 \mathrm{~cm}$. in diameter. 
Measurements of enzymic activities were made by methods previously described (Kleczkowski, 1944, 1946). Crystalline chymotrypsin was obtained from beef pancreas by the method described by Northrop (1939). After isolation and recrystallization as chymotrypsinogen, it was converted into chymotrypsin and recrystallized twice. Ribonuclease was isolated from beef pancreas, and was crystallized from ammonium sulphate solution by the method described by Kunitz (1940). In this state, however, preparations were unsuitable for use with virus $\boldsymbol{X}$, as they contained sufficient proteolytic activity to hydrolyse the virus. Hence, before use, the preparations were heated as described by Kleczkowski (1948), to destroy proteolytic activity but leaving much of the ribonuclease activity unimpaired.

Bacteria readily attack potato virus $X$, which is also destroyed by incubation with phosphate buffer around $\mathrm{pH} 7$ (Bawden \& Crook, 1947). All incubations were therefore made with solutions containing $0 \cdot 05-0 \cdot 1 \mathrm{M}$ boric acid borax buffer, which has sufficient antiseptic properties to prevent bacterial growth and is relatively innocuous towards the virus.

\section{Variation in the properties of virus during purification}

In attempts to find a method of purification that would give consistent results, various methods of clarifying the sap were tried, both singly and in combination. These were the addition of $\mathrm{Na}_{2} \mathrm{HPO}_{4}(10 \mathrm{~g}$./l.), freezing and thawing, and heating to $60^{\circ}$ before centrifuging for 15 min. at 3000 r.p.m. All of them produced clear brown supernatant fluids, and seemed to cause little loss of virus on the green sediments, but even the combination of all three failed to leave virus that would behave consistently. At this stage there are considerable differences between different lots of sap, indicating the wide range of virus concentration produced by the different strains in different host plants. Some lots of sap, especially those from tomato plants infected with $X^{\boldsymbol{Y}}$ or $\boldsymbol{X}^{\boldsymbol{K}}$ in the winter, show anisotropy of flow strongly and precipitate with virus antiserum when diluted as much as 1/5000. Others, for example, sap from tobacco plants infected with $X^{s}$ in the summer, show no anisotropy of flow and give precipitin titres of only $1 / 250$. There is, however, no correlation between virus concentration of the sap and behaviour during subsequent purification treatments: better preparations of virus can sometimes be made from samples of sap with low than with high virus contents, but not regularly.

The main difficulties in purifying virus $X$ are its tendency to become insoluble and the readiness with which it adsorbs other materials. When they first described a method for making liquid crystalline preparations, Bawden $\&$ Pirie (1938) commented on the greater difficulty of purifying virus $X$ than tobacco mosaic virus and suggested that their yields were probably only about one-fifth of the virus originally present in the sap. A treatment they found most valuable for obtaining consistent products was incubation with trypsin, but this destroyed some virus. As the main purpose of this work was to obtain virus $X$ in a form suitable for testing its susceptibility to ribonuclease, this treatment was inadmissible for fear that some residual trypsin might 
complicate subsequent tests with ribonuclease. The omission of this treatment is probably responsible for most of the difficulties encountered, and the attempt to substitute sedimentation in the ultracentrifuge as an alternative was far from successful. Any treatment that precipitates the virus, at any stage during the course of purification, is likely to cause a part or the whole of the virus to become insoluble. A precipitation procedure that may have been applied several times previously without rendering a significant fraction of the preparation insoluble, when repeated, may turn the major part or even the whole of the preparation insoluble. Bawden \& Pirie (1938) found that the brown precipitates discarded during the course of preparations contained some virus, but in our work the bulk of the virus has often been contained in insoluble pigmented material. There is little in the appearance and behaviour of such materials to suggest this, and they could easily be regarded as impurities whose removal would produce a useful fractionation.

No exact sequence or number of fractionations can be described for the purification of virus $X$ because the behaviour of different lots of sap is so variable that each has to be treated on its merits, but we have used various combinations of fractional precipitation and differential ultracentrifugation. All the virus can be precipitated from sap by quarter-saturation with $\left(\mathrm{NH}_{4}\right)_{2} \mathrm{SO}_{4}$ and it can usually be dissolved completely in a volume of water equal to a fifth of that of the original sap. Provided the fluids are kept neutral by the addition of $\mathrm{NaOH}$, precipitation and re-solution in water can be repeated many times without serious loss of virus, though occasionally, even at this early stage of preparation, the virus contained in the bulky chocolate-coloured precipitates produced by $\left(\mathrm{NH}_{4}\right)_{2} \mathrm{SO}_{4}$ dissolves incompletely or only slowly.

Each time a precipitate is suspended in water and centrifuged to separate insoluble material it is advisable to examine the supernatant fluids for anisotropy of flow. This provides a rapid test for the presence of the virus and shows whether most has dissolved or has remained on the precipitate. When the supernatant fluids from the ammonium sulphate precipitations are colourless, the redissolved precipitate is brought to $\mathrm{pH} 4.5$ with $\mathrm{HCl}$. This produces a variable result, sometimes precipitating all the virus, most often the greater part, but occasionally little or none. The differences are not correlated with virus strains of host plant, but different proportions of different preparations precipitate at different $\mathrm{pH}$ values. If a precipitate obtained at $\mathrm{pH} 4.5$ is taken up at $\mathrm{pH} 7$ and the fluid again adjusted to $4 \cdot 5$, it is usual for only a part of the preparation to precipitate. The treatment with acid, however, is useful, because it often denatures some contaminants that are not removed by the treatment with ammonium sulphate. The precipitate is taken up at $\mathrm{pH} \mathrm{7}$; if much virus remains in the supernatant fluid at $\mathrm{pH} 4.5$ this is neutralized, mixed with the virus that precipitated, and the mixture centrifuged to free from any insoluble material. Additional precipitations with $\left(\mathrm{NH}_{4}\right)_{2} \mathrm{SO}_{4}$ and re-solutions now usually remove further coloured contaminants, and it is also useful to sediment the virus by centrifuging $1 \mathrm{hr}$. at 30,000 r.p.m. However, any attempt to concentrate the virus to solutions containing more than about $5 \mathrm{mg} . / \mathrm{ml}$. is likely to lead to the separation of the virus in insoluble, or very slowly dissolving 
states. Often the pellets obtained by ultracentrifugation need extracting several times, using a total volume of water equal to that of the originally centrifuged fluid, before they resuspend completely and remain stable when centrifuged at $3000 \mathrm{r}$.p.m. The virus is more stable if suspended in $0.1 \mathrm{~m}$ borate buffer, $\mathrm{pH} 7$, than in water, and preparations that have remained stable during the course of several precipitations or ultracentrifugations may become wholly insoluble when dialysed against distilled water.

\section{Aggregation and disaggregation of virus particles}

The difficulty experienced in keeping virus $X$ in solution partly arises because, during purification and concentration, the virus particles aggregate linearly to such an extent that they become entangled one with another and form a mesh-like structure too bulky to give a stable suspension or solution. This lengthening and entanglement of the particles is clearly shown by electron micrograms of the virus preparations at different stages. In sap the virus occurs as separate particles varying greatly in length, but most are less than $500 \mathrm{~m} \mu$. long. In the insoluble preparations, on the other hand, individual particles are impossible to identify, and the long fibres are so intertwined that electron micrograms resemble pictures of fishing nets. In this condition the virus also ceases to show anisotropy of flow, or shows it much less than when the virus is in solution and present as individual rods. Insolubility, however, does not seem to result simply from the aggregation of virus particles, but is more probably also associated with the combination of the virus with some other materials. The fibres composing the insoluble preparations are coarser than the virus particles occurring in sap or than the elongated threads in purified soluble preparations. In addition, the mesh-like structure appears to contain particles of a different shape and denser material than the virus.

Bawden \& Pirie (1945) have shown that small particles of tobacco mosaic virus aggregate linearly when incubated with trypsin, and they suggest that the trypsin removes materials combined with the ends of the particles and sets free groups of the particles that then combine with one another. With this virus, aggregation does not proceed sufficiently far for the virus to come out of solution, or to sediment with low-speed centrifugation. Bawden \& Crook (1947) have described a similar aggregation of small particles of virus $X$ produced by short incubations with trypsin. It is possible, therefore, that virus $X$ particles as they originally occur in the sap are combined with materials that act as stabilizers, and whose removal during purification causes the particles to become increasingly aggregated, but this does not explain all the phenomena. For example, the degree of aggregation should be correlated with the purity of a preparation, as it is with tobacco mosaic virus, but this is not always so. Dark brown precipitates, which will not dissolve in water, often separate during the early stages of preparing virus $X$, and these are rich in highly aggregated virus. It is likely that in these conditions the virus has formed an insoluble complex by combining with some other constituent of sap. The insoluble virus seems to be fully infective and is serologically active, but suspensions show no anisotropy of flow. Incubation with trypsin restores 
anisotropy of flow and changes the character of electron micrograms from the fishing-net picture to one of more discrete, though still greatly elongated, particles. After incubating such precipitates at $37^{\circ}$ for 30 min. with $0.5 \%$ commercial trypsin, about $70 \%$ of their weight can be recovered in the form of soluble virus showing strong anisotropy of flow. The virus in such precipitates can also be brought into solution slowly by incubation at $37^{\circ}$ with $\mathrm{pH} 7 \cdot 5$ borate buffer, though 3 days' incubation may be needed to produce the same result as $\mathbf{3 0} \mathrm{min}$. with trypsin (Table 1 ).

Table 1. The effect of trypsin on a crude insoluble preparation of virus $X^{K}$

\begin{tabular}{|c|c|c|c|c|c|c|c|c|}
\hline \multirow{2}{*}{$\begin{array}{l}1.8 \% \text { virus } \\
\text { suspension } \\
\text { (ml.) }\end{array}$} & \multirow{2}{*}{$\begin{array}{l}0.2 \mathrm{~m} \mathrm{pH} 7 \cdot 5 \\
\text { borate buffer } \\
\text { (ml.) }\end{array}$} & \multirow{2}{*}{$\begin{array}{l}0.5 \% \\
\text { trypsin } \\
\text { (ml.) }\end{array}$} & \multirow{2}{*}{$\begin{array}{l}\mathrm{H}_{\mathbf{2}} \mathrm{O} \\
\text { (ml.) }\end{array}$} & \multicolumn{5}{|c|}{ Appearance of the fluid after (hr.) } \\
\hline & & & & $\mathbf{0}$ & 0.5 & 3 & 24 & 72 \\
\hline $1 \cdot 0$ & $\mathbf{3} \cdot \mathbf{0}$ & $0 \cdot 45$ & & $\overline{\text { op. }}$ & $\begin{array}{c}++ \\
\text { cl. }\end{array}$ & $\overline{c l}$. & $\overline{\mathrm{cl}}$. & $\overline{c l}$ \\
\hline $1 \cdot 0$ & $3 \cdot 0$ & & $0 \cdot 45$ & op. & оp. & op. & $\begin{array}{c}++ \\
\text { tr. }\end{array}$ & $\underset{\mathrm{cl} .}{++}$ \\
\hline
\end{tabular}

+ signs indicate the intensity of anisotropy of flow. - signs indicate no anisotropy of flow. op. = opaque, tr. = turbid, cl. = clear. The virus and trypsin (British Drug Houses) were both in water.

The action of trypsin and chymotrypsin on more highly purified preparations that have become insoluble can be spectacular. An example is given in Table 2. The virus preparation used was a colourless one that had become insoluble during dialysis. It formed an opaque suspension that slowly sedimented when allowed to stand undisturbed, and it showed no anisotropy of flow. Immediately the trypsin or chymotrypsin was added, the virus began to dissolve and anisotropy of flow began to develop, and within $30 \mathrm{sec}$. the fluids were clear and showed anisotropy of flow strongly. When incubated, anisotropy of flow decreased because of the hydrolysis of the virus, but the control incubated with borate buffer alone after $24 \mathrm{hr}$. had also begun to go into solution and to show slight anisotropy of flow. Precipitin tests can be made with the insoluble virus preparations, for they flocculate much more rapidly and at higher dilutions with virus antiserum than with saline or normal serum. Weight for weight the insoluble virus gives a smaller precipitin titre than soluble virus.

Table 2. Effects of chymotrypsin and trypsin on an insoluble preparation of potato virus $X^{S}$

\begin{tabular}{|c|c|c|c|c|c|c|}
\hline \multirow{2}{*}{$\begin{array}{c}0.5 \% \\
\text { suspension } \\
\text { of virus } \\
\text { (ml.) }\end{array}$} & \multirow{2}{*}{$\begin{array}{l}0.2 \mathrm{M} \mathrm{pH} 7.5 \\
\text { borate buffer } \\
\text { (ml.) }\end{array}$} & \multirow{2}{*}{$\begin{array}{l}0.25 \% \\
\text { chymo- } \\
\text { trypsin } \\
\text { (ml.) }\end{array}$} & \multirow{2}{*}{$\begin{array}{c}0.5 \% \\
\text { trypsin } \\
\text { (ml.) }\end{array}$} & \multicolumn{3}{|c|}{ Appearance of the fluid after } \\
\hline & & & & 30 sec. & $4 \mathrm{hr}$. & $24 \mathrm{hr}$. \\
\hline 0.4 & 0.4 & 0.2 & . & $+\underset{\mathrm{cl} .}{+}+$ & $\begin{array}{l}++ \\
\text { cl. }\end{array}$ & $\overline{c l}$ \\
\hline 0.4 & $0 \cdot 4$ & • & 0.2 & $\begin{array}{c}++ \\
\text { cl. }\end{array}$ & $\begin{array}{l}++ \\
\text { cl. }\end{array}$ & $\overline{c l}$. \\
\hline 0.4 & 0.6 & - & - & op. & op. & $\begin{array}{l}+ \\
t r\end{array}$ \\
\hline
\end{tabular}

Symbols as in Table 1 . The virus was suspended in water: crystalline chymotrypsin and B.D.H. trypsin were dissolved in $\mathrm{pH} 7 \cdot 5$ borate buffer. 
Treating the insoluble preparations with trypsin or chymotrypsin affects their serological reaction in various ways, corresponding with the changes in optical properties. The first effect of the enzymes, which cause the development of anisotropy of flow, leads to an increase in the precipitin titre, but with the loss of anisotropy of flow produced by hydrolysis during incubation the titre falls steadily. The development of anisotropy of flow caused by prolonged incubation with borate buffer also increases the precipitin titre, and reduces the spontaneous flocculations of the saline controls.

Table 3. Relative susceptibility of two strains of virus $X$ to chymotrypsin

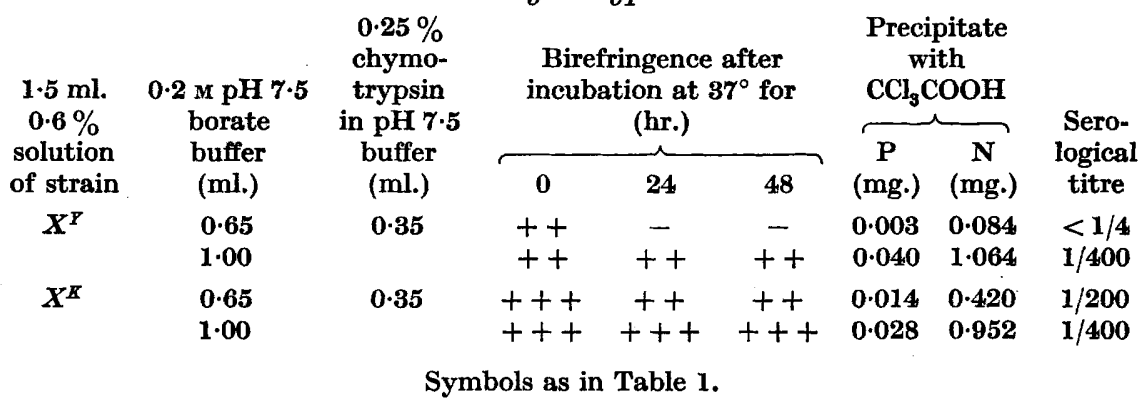

The mechanism of re-solution is uncertain, but two alternative explanations can be offered. One is that the lateral linking of the fibres of virus $X$ is brought about by impurities which are readily destroyed or replaced by trypsin and chymotrypsin. As the virus itself is broken down by trypsin, another equally likely explanation is that the splitting of a few of the entangled particles is sufficient to loosen the fibrous structure and allow the particles to separate one from the other and form a reasonably stable suspension. Electron micrograms of the insoluble preparations show the presence of material other than rod-like particles, which does perhaps support the suggestion of impurities being responsible. Also, if the phenomenon is caused by impurities, the differences between the behaviour of different preparations receives a ready explanation if we postulate different quantities of such impurities in different samples of sap. Whatever the explanation, it is clear that the interactions of virus $X$ and trypsin and chymotrypsin are complex. The enzymes cause small virus particles to aggregate, whereas they disrupt large insoluble aggregates, and prolonged incubation hydrolyses the protein itself. The first two effects seem to be produced equally with the three strains, but the different strains differ considerably in their susceptibility to the proteolytic action of both trypsin and chymotrypsin. Table 3 shows the results of one experiment in which preparations of $\boldsymbol{X}^{\mathbb{K}}$ and $\boldsymbol{X}^{\boldsymbol{Y}}$ were incubated under comparable conditions with chymotrypsin. It will be seen that $X^{Y}$ lost anisotropy of flow, ability to precipitate with virus antiserum and precipitability with trichloroacetic acid more rapidly than $X^{K}$. Strain $X^{S}$ is intermediate. In contrast to casein, which is digested more readily by trypsin than chymotrypsin, all three strains of virus $X$ are hydrolysed more rapidly by chymotrypsin than by trypsin. 


\section{Properties of nucleic acid from virus $\boldsymbol{X}$}

Sometimes the whole of the virus in a preparation becomes insoluble, but more often a part can be obtained as a colourless stable solution, spontaneously birefringent if more concentrated than $1 \%$ and showing strong anisotropy of flow if more dilute. Preparations in this condition have been used for the preparation of nucleic acid and for testing the effects of ribonuclease. The carbohydrate content of these preparations has varied from 4 to $7 \%$, instead of $\mathbf{2 . 5} \%$ found by Bawden \& Pirie (1938) for their most highly purified preparations. Bawden \& Pirie (1938) and Loring (1938) have described the separation of crude nucleic acid from virus $X$ preparations denatured by heat or by treatment with glacial acetic acid, but did not establish its identity. We have isolated nucleic acid from virus $X$ by various methods, of which the most successful was that described by Johnson \& Harkins (1929) for the isolation of yeast nucleic acid. By this method $75 \%$ of the phosphorus originally present in the virus preparation was recovered in the form of a protein-free nucleic acid. The virus solutions were incubated with $0.85 \mathrm{~N} \mathrm{NaOH}$ at $0^{\circ}$ for $2 \mathrm{hr}$., brought to $\mathrm{pH} 6$ with glacial acetic acid and centrifuged free from the denatured protein. This protein contained only traces of phosphorus, but from $\mathbf{1 . 5}$ to $4.5 \%$ carbohydrate, depending on the original content of the preparation. The nucleic acid was then precipitated from the clear supernatant fluid by adjusting to $\mathrm{pH} 3$ with $3 \mathrm{~N} \mathrm{HCl}$ and adding an equal volume of $95 \%$ ethanol, and washed first with absolute ethanol and then with ether. The dried material contains about $7 \%$ phosphorus, $14 \%$ nitrogen and $33 \%$ carbohydrate and dissolves in water at $\mathrm{pH} 5-6$. The $\mathrm{pH}$ should be kept below 7 , for at room temperature the nucleic acid depolymerizes rapidly in alkaline solutions and soon ceases to be precipitable by $0.5 \mathrm{~N} \mathrm{HCl}$. Solutions give a bluish green colour with Bial's reagent and no colour with diphenylamine reagent in acetic acid (Dische, 1930), indicating that it is a nucleic acid of the ribose, and not desoxyribose, type. Incubating a $0.1 \%$ solution with $0.01 \%$ ribonuclease at $\mathrm{pH} 6.5$ for $3 \mathrm{hr}$. at $37^{\circ}$ rendered the nucleic acid no longer precipitable by $0.5 \mathrm{~N} \mathrm{HCl}$. After incubation in similar conditions, and for the same length of time, without ribonuclease, half the nucleic acid was precipitable. In comparative tests with commercial preparations of nucleic acid from yeast and the nucleic acids from potato virus $X$ and tobacco mosaic viruses, those from the two viruses depolymerized at the same rates with ribonuclease and with alkali alone, but the yeast. nucleic acid was depolymerized more slowly. Whether this is because a different method of manufacture was used for the yeast nucleic acid or because of a real difference between the yeast and virus nucleic acids is unknown.

\section{Reactions between ribonuclease and virus preparations}

The interactions of tobacco mosaic virus and ribonuclease have been described by Loring (1942) and Kleczkowski (1946). When the two are mixed in salt-free solutions the virus is precipitated in the form of paracrystalline threads which redissolve immediately salt is added. When the two are mixed 
in $0 \cdot 1 \mathrm{M}$ borate buffer at $\mathrm{pH} 7$ there is initial precipitation, but the fluids become clear after standing for $30 \mathrm{~min}$. at room temperature. At concentrations at which there is no precipitation, combination between the virus and the enzyme can be demonstrated by sedimenting the virus in the ultracentrifuge. The addition of the enzyme to the virus causes an immediate drop in infectivity, but the infectivity can be restored by diluting the mixture. There is no additional effect when the mixtures of virus and enzyme are incubated. The interactions of ribonuclease and potato virus $X$ in some ways resemble those of the enzyme and tobacco mosaic virus, but there are differences. Some of the differences in the behaviour with ribonuclease closely simulate the differences encountered during the purification of the two viruses.

Table 4. Comparison of the amount of ribonuclease (RNase) combining with virus $X^{Y}$ and tobacco mosaic virus (T.M.V.)

\begin{tabular}{|c|c|c|}
\hline \multirow[b]{2}{*}{$\begin{array}{c}\text { Materials contained in } 7.5 \mathrm{ml} . \mathrm{H}_{2} \mathrm{O} \\
\text { at } \mathrm{pH} 6.0 \text { (mg.) }\end{array}$} & \multicolumn{2}{|c|}{$\begin{array}{c}\text { Ribonuclease activity (as percentage } \\
\text { of control) in }\end{array}$} \\
\hline & Supernatant fluid & Resuspended pellet \\
\hline 6 virus $X+1.5$ RNase & 80 & 20 \\
\hline 6 virus $X$ & $\mathbf{0}$ & $\mathbf{0}$ \\
\hline 6 T.M.V.+1.5 RNase & 23 & 77 \\
\hline 6 T.M.V. & $\mathbf{0}$ & o \\
\hline 1.5 RNase & 100 & No pellet \\
\hline
\end{tabular}

The mixtures were centrifuged for $1 \mathrm{hr}$. at 40000 r.p.m., when the supernatant fluids were decanted and the pellets were resuspended $\mathrm{m}$ water. The ribonuclease activities of the supernatant fluid and pellet were then estimated.

When ribonuclease and virus $X$ are mixed at $\mathrm{pH}$ values between their isoelectric points, the fluids become opalescent, more viscous and lose their anisotropy of flow. There is no separation of obvious floccules, but low-speed centrifugation produces a sediment. There is the same phenomenon whether the solutions are salt-free or in $\mathbf{0 . 1} \mathrm{m}$ borate buffer, and the addition of salt to opalescent salt-free mixtures does not increase their clarity or restore their anisotropy of flow. These viscous, opalescent mixtures resemble the insoluble fractions of virus $X$ preparations that separate during the course of purification. When used in precipitin tests the mixtures give lower precipitin titres than the soluble virus, and in the presence of borate buffer they slowly become clear, recover their anisotropy of flow and original precipitin titres. The process of re-solution is greatly accelerated by the addition of chymotrypsin, though this does not cause such immediate changes as with the insoluble virus preparations used for the tests shown in Table 2. To quote one experiment: a mixture containing $0.1 \%$ virus and $0.05 \%$ ribonuclease in $0.05 \mathrm{M}$ borate buffer at pH $7 \cdot 3$ became clear and regained its full anisotropy after $16 \mathrm{hr}$. at room temperature after the addition of $0.5 \mathrm{mg}$. chymotrypsin $/ \mathrm{ml}$., whereas the mixture in buffer alone required $36 \mathrm{hr}$. for this to occur.

As with tobacco mosaic virus, combination between virus $X$ and ribonuclease can be demonstrated by mixing the two, ultracentrifuging the mixtures and assaying the supernatant fluids and resuspended pellets for their content of the enzyme. The results of one such experiment are given in Table 4, which shows 
that $6 \mathrm{mg}$. virus in these conditions combined with $0.3 \mathrm{mg}$. ribonuclease. In similar conditions tobacco mosaic virus combined with about four times as much ribonuclease. The comparison is of some interest, for despite the fact that weight for weight virus $\boldsymbol{X}$ combines with less of the enzyme than tobacco mosaic virus, its infectivity is more strongly inhibited by ribonuclease. Apart from quantitative differences in the amounts of ribonuclease required to cause inhibition, the inhibition of the two viruses seems to follow the same course, inhibition occurring immediately ribonuclease and virus $X$ are mixed and infectivity being recovered by sufficient dilution. Inoculating with solutions containing $10^{-4}$ or $10^{-5} \mathrm{~g}$. virus $/ \mathrm{ml}$., the concentration of ribonuclease needs to be reduced below $10^{-6} \mathrm{~g} . / \mathrm{ml}$. before it ceases to cause any appreciable inhibition of infectivity. In attempts to assess any inactivation, as distinct from inhibition, by infectivity measurements, tests were made with inocula containing less than $10^{-6} \mathrm{~g} . / \mathrm{ml}$. ribonuclease.

The effects of mixing ribonuclease and virus $X$ have been reasonably constant with all the virus preparations used, but great variations have been encountered with different preparations that have been incubated with the enzyme. It is clear that ribonuclease has no effects comparable with those of the proteolytic enzymes. Incubation with concentrations of the enzyme $(0.001 \%)$ that rapidly attack the separated virus nucleic acid have no effect on the intact virus. Differences in the behaviour of preparations incubated with and without ribonuclease occur only when the enzyme concentration exceeds $0.025 \%$. Even at higher concentrations there was no destruction of virus when infective sap was incubated, and with no purified preparation has the virus been completely, or largely, destroyed, as it is when incubated with proteolytic enzymes. With this one exception, however, almost every possible result has been obtained with different purified preparations of the virus incubated with concentrated solutions of ribonuclease. Repeated tests with the same virus preparation have given consistent results, but using different preparations some have suffered considerable inactivation as shown by falls in infectivity and precipitin titre, whereas others have been unaffected and the rest have shown increases in both infectivity and precipitin titre. The different results are not correlated with the use of different virus strains or host plants, for all have been encountered with different preparations of strain $X^{K}$ propagated in tomato plants. The preparations which have shown increases in infectivity and precipitin titre during incubation are merely reversing the fall in these two activities occasioned by the virus combining with the enzyme and separating in an insoluble form. During incubation the virus again dissolves, regains anisotropy of flow and its precipitin titre and infectivity are restored to their original. This re-solution does not seem to be brought about by any change in either the virus or enzyme, for both can be recovered with full activity. These phenomena are illustrated in Table 5, which shows that while the infectivity and precipitin titre of a virus-ribonuclease mixture were increasing during incubation, the infectivity and titre of a control solution incubated with buffer alone were falling.

Variable results have also been obtained in tests made to determine whether 
incubation with ribonuclease has any effect on the elementary composition of virus $X$ (Table 6). After incubating virus preparations with and without ribonuclease at $37^{\circ}$ for various periods up to $48 \mathrm{hr}$. at $\mathrm{pH} 7 \cdot 5$, the virus was either sedimented by ultracentrifuging or precipitated by adding an equal

Table 5. The increase of infectivity and precipitin titre when a mixture of virus $X^{K}$ and ribonuclease was incubated

Contents of mixtures

\begin{tabular}{|c|c|c|c|c|c|c|c|c|c|c|c|c|}
\hline \multirow{2}{*}{$\begin{array}{c}0.4 .5 \% \\
\text { water } \\
\text { solution } \\
\text { of virus } \\
\text { (ml.) }\end{array}$} & \multirow{2}{*}{$\begin{array}{c}0.2 \mathrm{M} \\
\mathrm{pH} \% \cdot 2 \\
\text { borate } \\
\text { buffer } \\
(\mathrm{ml} .)\end{array}$} & \multirow{2}{*}{$\begin{array}{c}0 \cdot 1 \% \\
\text { RNase } \\
\text { in } \\
\text { pH 7.2 } \\
\text { buffer } \\
\text { (ml.) }\end{array}$} & \multicolumn{3}{|c|}{$\begin{array}{l}\text { Appearance of the } \\
\text { mixtures after (hr.) }\end{array}$} & & \multicolumn{3}{|c|}{$\begin{array}{l}\text { Infectivity } \\
\text { (numbers of } \\
\text { lesions/leaf) } \\
\text { after (hr.) }\end{array}$} & \multicolumn{3}{|c|}{$\begin{array}{l}\text { Serological } \\
\text { precipitin } \\
\text { titre after } \\
\text { (hr.) }\end{array}$} \\
\hline & & & 0 & 24 & 48 & & 0 & 24 & 48 & 0 & 24 & 48 \\
\hline 4.5 & . & $3 \cdot 0$ & $\begin{array}{c}+ \\
\text { op. }\end{array}$ & $\begin{array}{c}++ \\
\text { tr. }\end{array}$ & $\begin{array}{c}++ \\
\text { tr. }\end{array}$ & $\begin{array}{l}1 / 50 * \\
1 / 500^{*}\end{array}$ & $\begin{array}{l}1 \\
2\end{array}$ & $\begin{array}{l}10 \\
10\end{array}$ & $\begin{array}{l}26 \\
12\end{array}$ & $\frac{1}{600}$ & $\frac{1}{800}$ & $\frac{1}{1200}$ \\
\hline 4.5 & $3 \cdot 0$ & - & $\underset{\text { cl. }}{++}$ & $\underset{\text { cl. }}{++}$ & $\begin{array}{c}+++ \\
\text { cl. }\end{array}$ & $\begin{array}{l}1 / 50^{*} \\
1 / 500^{*}\end{array}$ & $\begin{array}{r}150 \\
61\end{array}$ & & $\begin{array}{r}110 \\
41\end{array}$ & $\frac{1}{2500}$ & & $\frac{1}{1600}$ \\
\hline
\end{tabular}

RNase $=$ ribonuclease. Symbols as in Table 1 .

* Dilutions at which the mixtures were used in the infectivity tests.

Table 6. The various effects of incubation with ribonuclease on elementary composition of different preparations of virus $X^{K}$

\begin{tabular}{|c|c|c|c|c|c|c|c|}
\hline \multirow[b]{2}{*}{$\begin{array}{l}\text { Virus } \\
\text { preparation* }\end{array}$} & \multicolumn{3}{|c|}{ Mixtures } & \multicolumn{4}{|c|}{$\begin{array}{l}\text { Precipitates with } \mathrm{CCl}_{3} \mathrm{COOH} \\
\text { from } 2.5 \mathrm{ml} \text {. of each mixture }\end{array}$} \\
\hline & $\begin{array}{c}0.6 \% \text { water } \\
\text { solution } \\
\text { of virus } \\
\text { (ml.) }\end{array}$ & $\begin{array}{c}0.2 \mathrm{м} \mathrm{pH} 7.5 \\
\text { borate buffer } \\
\text { (ml.) }\end{array}$ & $\begin{array}{c}0 \cdot 1 \% \text { RNase } \\
\text { in pH } 7 \cdot 5 \\
\text { buffer } \\
\text { (ml.) }\end{array}$ & Imme & $\overbrace{\mathbf{N}(\mathrm{mg} .)}^{\text {diately }}$ & $\stackrel{\text { After }}{\text { P(mg. }}$ & $\underbrace{48 \mathrm{hr} .}_{\mathrm{N}(\mathrm{mg} .)}$ \\
\hline $\mathbf{A} \dagger$ & $\begin{array}{l}\mathbf{3} \\
\mathbf{3}\end{array}$ & $\dot{3}$ & $\begin{array}{l}3 \\
\cdot\end{array}$ & $\begin{array}{r}0 \cdot 032 \\
0 \cdot 033\end{array}$ & $\begin{array}{l}1 \cdot 11 \\
1 \cdot 09\end{array}$ & $\begin{array}{l}0 \cdot 021 \\
0 \cdot 021\end{array}$ & $\begin{array}{l}0 \cdot 97 \\
0 \cdot 95\end{array}$ \\
\hline $\mathbf{B}$ & $\begin{array}{l}\mathbf{3} \\
\mathbf{3}\end{array}$ & $\dot{3}$ & $\begin{array}{l}3 \\
\cdot\end{array}$ & $\begin{array}{l}0.030 \\
0 \cdot 030\end{array}$ & $\begin{array}{l}1 \cdot 05 \\
1 \cdot 03\end{array}$ & $\begin{array}{l}0 \cdot 020 \\
0 \cdot 028\end{array}$ & $\begin{array}{l}0 \cdot 90 \\
0 \cdot 99\end{array}$ \\
\hline $\mathbf{C}$ & $\begin{array}{l}\mathbf{3} \\
\mathbf{3}\end{array}$ & $\dot{3}$ & $\begin{array}{l}3 \\
\cdot\end{array}$ & $\begin{array}{l}0.029 \\
0.029\end{array}$ & $\begin{array}{l}0 \cdot 99 \\
0 \cdot 98\end{array}$ & $\begin{array}{l}0 \cdot 025 \\
0 \cdot 026\end{array}$ & $\begin{array}{l}0 \cdot 88 \\
0 \cdot 90\end{array}$ \\
\hline $\mathbf{D}$ & $\begin{array}{l}\mathbf{3} \\
\mathbf{3}\end{array}$ & $\dot{3}$ & $\begin{array}{l}3 \\
\cdot\end{array}$ & $\begin{array}{l}0 \cdot 027 \\
0 \cdot 027\end{array}$ & $\begin{array}{l}0.92 \\
0.91\end{array}$ & $\begin{array}{l}0 \cdot 021 \\
0 \cdot 022\end{array}$ & $\begin{array}{l}0.78 \\
0.79\end{array}$ \\
\hline $\mathbf{E}$ & $\begin{array}{l}\mathbf{3} \\
\mathbf{3}\end{array}$ & $\dot{\mathbf{3}}$ & $\begin{array}{l}3 \\
.\end{array}$ & $\begin{array}{l}0 \cdot 030 \\
0.030\end{array}$ & $\begin{array}{l}1 \cdot 10 \\
1 \cdot 08\end{array}$ & $\begin{array}{l}0.022 \\
0.028\end{array}$ & $\begin{array}{l}1 \cdot 00 \\
1 \cdot 05\end{array}$ \\
\hline
\end{tabular}

* A was isolated by fractional centrifugation alone; B, C, D and E by precipitation with acid and ammonium sulphate.

$\dagger$ A, from frozen sap of tomato plants; B, from frozen sap of tomato plants; C, from frozen and heated sap of tomato plants; $D$, from frozen sap of tobacco plants; $E$, from frozen and heated sap of tobacco plants.

volume of $10 \%(\mathrm{w} / \mathrm{w})$ trichloroacetic acid and centrifuged. The pellets were then analysed for their content of phosphorus and nitrogen. In many experiments incubation with the enzyme has caused no more change in the composition of the virus than has incubation with buffer alone, but with some preparations incubation with ribonuclease has apparently caused a loss of varying amounts of phosphorus up to $30 \%$ of that initially present. The 
preparations in which loss of phosphorus occurred were those in which incubation with ribonuclease also led to a drop in the precipitin titre and a loss of infectivity. Hence it does not seem that the variable results can be attributed to the presence or absence of a phosphorus-containing impurity that was attacked by the enzyme. Nor is there any evidence that such impurities occur, for the phosphorus content of crude preparations is always below that of carefully purified ones, and the apparent inactivation by ribonuclease has occurred with some of the most highly purified viruses.

No positive interpretation of these variable results can be given, but it seems most likely that ribonuclease has no enzymic activity against virus $X$ and that the variations are caused by the presence of variable amounts of impurities that act as stabilizers against the injurious effects of incubation alone. Bawden $\&$ Crook (1947) have found that purified preparations of virus $X$ are inactivated by incubation with phosphate buffer at $\mathrm{pH} 7$ and $37^{\circ}$ and that this inactivation is accompanied by a separation of the nucleic acid from the protein. This inactivation does not proceed to completion, but leaves a residuum of serologically active virus, and the amount of inactivation reached depends on the state of purity of the preparation. Inactivation does not occur when infective sap is incubated with phosphate and the inactivation of purified preparations can be prevented by the addition of healthy plant sap and by some protein solutions. Compared with phosphate buffer, borate caused little inactivation but this is probably the effect responsible for our variable results. When we have incubated infective sap with borate buffer, with and without ribonuclease, we have not found any loss of either infectivity or serological activity. With purified preparations, however, there has always been some loss of virus by incubation with borate buffer alone, though the amount of loss has varied from preparation to preparation. This loss is more clearly shown by the elementary analyses than by the precipitin titres or infectivity tests, as these are complicated by the virus being rendered insoluble by combining with ribonuclease and its re-solution during incubation. This phenomenon can account for the occasional rises in infectivity and precipitin titres during incubation, and probably happened in preparations containing sufficient stabilizing impurities to prevent inactivation by the borate buffer. In preparations containing less of these impurities, inactivation would proceed, and in some does proceed, sufficiently far for the beneficial effects on infectivity and precipitin titre of re-solution of the virus to be overcome, with a resulting drop in activity. Where incubation with ribonuclease has carried decomposition further than incubation with borate buffer alone, it seems likely that the enzyme has merely acted by removing degradation products of the virus and moving the state of equilibrium further towards complete inactivation. 


\section{REFERENCES}

Bawden, F. C. \& Crook, E. M. (1947). Some properties of potato virus $X$ in leaf extracts made in different ways. Brit. J. exp. Path. 28, 403.

Bawden, F. C. \& Pirie, N. W. (1936). Experiments on the chemical behaviour of potato virus $X$. Brit. J. exp. Path. 17, 64.

Bawden, F. C. \& Pirie, N. W. (1937). The isolation and some properties of liquid crystalline substances from solanaceous plants infected with three strains of tobacco mosaic virus. Proc. Roy. Soc. B, 123, 274.

Bawden, F. C. \& Pirie, N. W. (1938). Liquid crystalline preparations of potato virus $X$. Brit. J. exp. Path. 19, 66.

Bawden, F. C. \& Pirie, N. W. (1945). The separation and properties of tobacco mosaic virus in different states of aggregation. Brit. J. exp. Path. 26, 294.

Dische, Z. (1930). Ueber einige neue charakteristische Farbreaktionen der Thymonukleinsäure und eine Mikromethode zur Bestimmung derselben in tierischen Organen mit Hilfe dieser Reaktionen. Mikrochemie, 8, 4.

Johnson, T. B. \& Harkins, H. H. (1929). The examination of yeast nucleic acid for 5-methylcytosine. J. Amer. chem. Soc. 51, 1779.

KLeCzKowski, A. (1944). Combination of potato virus $X$ and tobacco mosaic virus with pepsin and trypsin. Biochem. J. 38, 160.

KLeCzkowski, A. (1946). Combinations between different proteins and between proteins and yeast nucleic acid. Biochem. J. 40,677.

KLeczkowski, A. (1948). Proteolytic activity of preparations of crystallized ribonuclease. Biochem. J. 42, 523.

Kunitz, M. (1940). Crystalline ribonuclease. J. gen. Physiol. 24, 15.

Loring, H. S. (1938). Properties of the latent mosaic virus protein. J. biol. Chem. $126,455$.

Loring, H. S. (1942). The reversible inactivation of tobacco mosaic virus by crystalline ribonuclease. J. gen. Physiol. 25, 497.

Northrop, J. H. (1939). Crystalline Enzymes. New York: Columbia University Press. 